\title{
ANALISIS PRODUKTIVITAS KERJA KARYAWAN DIKAITKAN DENGAN TIME MANAGEMENT
}

\author{
Elmira Febri Darmayanti \\ efdarmayanti@gmail.com \\ Universitas Muhammadiyah Metro, Lampung-Indonesia
}

\begin{abstract}
The increasing of society demand service of health will be more certifiable, effective, and reached these days oblige organizer of hospital to be more professional in conducting hospital management. The Apotek coordination with one of Installation Pharmacy under Governmental Hospital in West Java. Service factor placing human resource as an important element in it. Performance of Apotek's employees determine satisfaction level of pharmacy services which is given to patient. So that, employees work productivity of the Apotek give an important contribution in pharmacy service system specially and service system of Hospital in general.

The measurement method that used is work load, by using spot sampling method, which is representing work sampling pursuant to activity done at certain time dot and assumed to deputize an activity at that time dot. This method based on work characteristic, which are not chronological and requiring much time. Here in after analyzed about operating process as a whole, so that can be given alternatives for repairing process from time management. Its result indicate that entirely operation process at the Apotek will be able to influence employees performance. For that, after analysed we propose to repair the operation system.
\end{abstract}

Key Words : Productivity, Work Load, and Time Management.

\section{PENDAHULUAN}

\section{Latar Belakang Penelitian}

Kegiatan farmasi rumah sakit terdiri dari pendistribusian dan pelayanan farmasi yang ditangani oleh Apotek dan Instalasi Rumah Sakit. Pelayanan kefarmasian menurut Permenkes No. 58 Tahun 2014 merupakan suatu pelayanan langsung dan bertanggung jawab kepada pasien yang berkaitan dengan sediaan farmasi dengan maksud mencapai hasil yang pasti untuk meningkatkan mutu hidup pasien. Apotek menurut Permenkes No.35 Tahun 2014 merupakan sarana pelayanan kefarmasian tempat dilakukan praktik kefarmasian oleh Apoteker. Peranan apotek itu sendiri menjadi penting karena obat merupakan komponen yang menunjang efektivitas pelayanan dan pada umumnya menelan $40 \%$ dari biaya pengobatan pasien. Sehingga manajemen obat oleh Apotek memberikan kontribusi yang penting dalam sistem pelayanan farmasi Rumah Sakit.

Ada dua macam sumber daya yang sangat berperan dalam pelayanan serta pengendalian transaksi obat dan alat kesehatan yaitu meliputi sumber daya manusia dan sumber daya teknologi. Sumber daya manusia yang handal sangat dibutuhkan dalam mengelola manajemen obat di Apotek. Faktor pelayanan menempatkan sumber daya manusia sebagai unsur penting didalamnya. Kinerja para karyawan Apotek menentukan tingkat kepuasan pasien akan pelayanan yang diberikan, sehingga produktivitas kerja dari karyawan Apotek memberikan kontribusi yang penting dalam sistem pelayanan farmasi khususnya dan sistem pelayanan farmasi Rumah Sakit pada umumnya. 
Sedangkan pemanfaatan sumber daya teknologi dapat digunakan sebagai penunjang dalam proses bisnis serta pelayanan profesi farmasi. Pemanfaatan teknologi diantaranya adalah data-data akumulasi dan perancangan berbagai tools untuk kepentingan evaluasi dan pengendalian.

Sumber daya manusia yang bekerja pada Apotek ini terdiri dari apoteker, asisten apoteker, reseptur, tenaga administrasi, serta para programmer dan sistem analis. Karena Apotek ini berada pada sebuah Instalasi Farmasi Rumah Sakit dengan luas dan ruang pelayanan kesehatan yang tersebar, maka kendala yang dihadapi adalah tuntutan kerja pada banyak depo (outlet pelayanan farmasi/apotek).

Pada pelaksanaannya ada jam-jam dan hari-hari tertentu yang menjadi peak hours dan peak days. Untuk peak hours adalah dari jam 10.00 WIB hingga 13.00 WIB, sedangkan untuk peak days adalah hari Senin hingga Kamis. Diluar jam-jam tersebut beban kerja para karyawan menjadi berkurang.

Kegiatan pelayanannya terdiri dari beberapa proses yaitu operasi, pemeriksaan, transportasi dan penyimpanan yang dilakukan oleh masing-masing karyawan sesuai dengan profesi dan job description-nya. Ada lima unsur utama yang mengalir dalam proses pelayanan obat ini yaitu obat, resep, defekta (form permintaan obat rutin)/ aderet (form permintaan obat tidak rutin), data SIM, dan aliran uang (baik kas maupun bukti transfer dari bank).

Karena kegiatan pelayanan obat dalam apotek ini membutuhkan waktu yang cukup lama dilihat dari banyaknya jumlah pasien dan proses yang cukup panjang, maka dibutuhkan manajemen waktu yang baik sehingga karyawan apotek dapat memberikan pelayanan yang memuaskan bagi para pasien/pembawa resep. Manajemen waktu adalah kemampuan untuk memprioritaskan, menjadwalkan, dan melaksanakan tanggung jawab individu demi kepuasan individu tersebut. (Jones, 2012)

\section{Permasalahan}

Berdasarkan pada uraian latar belakang di atas, maka penulis mengangkat permasalahan dalam penelitian ini, yaitu: "Bagaimana produktivitas kerja karyawan pada Apotek apabila dikaitkan dengan time management"

\section{Batasan Masalah}

Kompleksnya masalah sumber daya manusia dalam sistem pelayanan Apotek ini membuat penulis harus membatasi secara tegas permasalahan-permasalahan yang akan dijadikan objek penelitian dan pembahasannya. Untuk itu, penulis membuat batasan permasalahan pada pengukuran produktivitas karyawan di depo OPD 2 (depo rawat jalan) dan IPD (depo rawat inap) yang merupakan depo-depo besar dihubungkan dengan time management:

a. Total jam kerja, beban kerja, dan tingkat kesalahan yang dilakukan oleh pegawai apotek.

b. Cara meningkatkan produktivitas (diluar waktu-waktu kritis) serta sistem control/monitoring yang bisa digunakan.

\section{Tujuan Penelitian}

Tujuan dari penelitian ini antara lain:

a. Untuk mengetahui total jam kerja, beban kerja, dan tingkat kesalahan yang dilakukan oleh pegawai apotek.

b. Untuk mengetahui cara meningkatkan produktivitas (diluar waktu-waktu kritis) serta sistem control/monitoring yang bisa digunakan. 


\section{KAJIAN TEORITIK \\ Beban Kerja}

Menurut Munandar (2012) mengemukakan beban kerja adalah suatu kondisi dari pekerjaan dengan uraian tugasnya yang harus diselesaikan pada batas waktu tertentu. Menpan dalam Dhania (2010) beban kerja adalah sekumpulan atau sejumlah kegiatan yang harus diselesaikan oleh suatu unit organisasi atau pemegang jabatan dalam jangka waktu tertentu. Menurut Permendagri No.12/2008, beban kerja adalah besaran pekerjaan yang harus dipikul oleh suatu jabatan atau unit organisasi dan merupakan hasil kali antara volume kerja dan norma waktu.

Sedangkan menurut Undang-Undang Kesehatan No.36 Tahun 2009 beban kerja adalah besaran pekerjaan yang harus dipikul oleh suatu jabatan/unit organisasi dan merupakan hasil kali antara jumlah pekerjaan dengan waktu. Setiap pekerja dapat bekerja secara sehat tanpa membahayakan dirinya sendiri maupun masyarakat di sekelilingnya, untuk itu perlu dilakukan upaya penyerasian antara kapasitas kerja, beban kerja, dan lingkungan kerja agar, sehingga diperoleh produktivitas kerja yang optimal.

Dengan demikian pengertian beban kerja adalah sebuah proses yang dilakukan oleh seseorang dalam menyelesaikan tugas-tugas suatu pekerjaan atau kelompok jabatan yang dilaksanakan dalam keadaan normal dalam suatu jangka waktu tertentu.

Secara terminologi yang dimaksud dengan beban kerja adalah beban yang timbul sebagai dampak dari dikenakannya pekerjaan (adanya tugas, wewenang, dan tanggung jawab jabatan) pada seorang pemegang jabatan dalam wujud ukuran-ukuran pemakaian waktu kerja dan tingkat beban psiko-fisik. Sedangkan sampling pekerjaan merupakan observasi yang dilakukan dalam interval waktu tertentu secara acak terhadap sejumlah sampel karyawan.

Karakteristik Beban Waktu Kerja :

1. Artikulasi Hasil Pengukuran

- Distribusi pemakaian waktu sepanjang jam kerja

- Menunjukkan tingkat aktivitas dan delay

- Pengukuran waktu baku

2. Aplikasi Hasil Pengukuran

- Distribusi pemakaian waktu: beban waktu kerja pegawai

- Tingkat pemanfaatan mesin/fasilitas

- Tingkat kebutuhan fasilitas dan tenaga kerja

- Prediksi kebutuhan pegawai ke depan

- Estimasi kelonggaran suatu pekerjaan

Adapun standar asumsi yang digunakan adalah 0-35\% diasumsikan beban kerja rendah, 35\%-75\% diasumsikan beban kerja sedang sementara $80 \%-100 \%$ diasumsikan beban kerja tinggi. Diatas $100 \%$ diasumsikan beban kerja sangat tinggi sehingga dibutuhkan adanya suatu usaha seperti penambahan waktu kerja (lembur) atau penambahan jumlah karyawan.

\section{Time Management dan Produktivitas}

Menurut Singh \& Jain, 2013 time management adalah tindakan atau proses perencanaan dan pelaksanaan pantauan sadar atas sejumlah waktu yang digunakan untuk aktivitas khusus, terutama untuk meningkatkan efektivitas, efisiensi, dan produktivitas.

Atau seperti dikatakan Humes dalam Adebisi (2013) time management secara singkat dapat diartikan sebagai suatu seni mengatur, mengorganisasi, menjadwalkan, serta menganggarkan waktu seseorang untuk menghasilkan kerja lebih efektif dan produktif. Waktu adalah sumber daya berharga, tidak dapat diganti dan tidak dapat diubah. Maka dari itu, sangat perlu untuk menggunakan waku dengan bijaksana. Time 
management mencakup tindakan menata, menjadwal, mengorganisasi, dan mengalokasikan setiap waktu seseorang yang digunakan untuk menyelesaikan tugastugas hariannya.

Menurut L. Greenberg dalam Sinungan (2008) mendefinisikan produktivitas sebagai perbandingan antara totalitas pengeluaran (output) pada waktu tertentu dibagi totalitas masukan (input) selama periode tersebut. Dengan kata lain bahwa produktivitas memliliki dua dimensi. Dimensi pertama adalah efektivitas yang mengarah kepada pencapaian target berkaitan dengan kuantitas, kualitas, dan waktu. Yang kedua yaitu efisiensi yang berkaitan dengan upaya membandingkan input dengan realisasi penggunaannya atau bagaimana pekerjaan tersebut dilaksanakan.

Menurut Herjanto (2007) produktivitas merupakan suatu ukuran yang menyatakan bagaimana baiknya sumber daya diatur dan dimanfaatkan untuk mencapai hasil yang optimal.

Dan menurut International Labour Office (ILO) produktivitas bukan hanya sekedar kerja keras, produktivitas selalu berisi dari elemen-elemen dari pembagian keuntungan, kerja tim, humanity, kepuasan dan teknologi.

Unsur-unsur produktivitas:

1. Efisiensi: merupakan suatu ukuran kehematan penggunaan sumber daya perusahaan dengan membandingkan antar penggunaan sumber daya yang sebenarnya (yang ada saat ini) dengan penggunaan sumber daya yang wajar atau standar.

2. Efektivitas: merupakan suatu ukuran yang memberikan gambaran seberapa jauh atau seberapa mudah target dapat tercapai baik secara kualitas ataupun waktu.

3. Kualitas: merupakan suatu ukuran yang menyatakan seberapa jauh telah memenuhi berbagai persyaratan, spesifikasi, dan atau harapan konsumen.

Produktivitas juga mengandung pengertian sikap mental yang selalu mempunyai pandangan bahwa mutu kehidupan akan selalu mengalami peningkatan, dimana hari ini harus lebih baik dari hari kemarin, dan hari esok harus lebih baik dari hari ini. Secara umum, produktivitas mengandung pengertian perbandingan antara hasil yang dicapai dengan keseluruhan sumber daya yang dipergunakan. Produktivitas tenaga kerja mengandung pengertian perbandingan antara hasil yang dicapai dengan peran serta tenaga kerja persatuan waktu.

Produktivitas pada saat ini menjadi semakin penting karena dianggap merupakan nilai tambah dari suatu organisasi dan selalu harus ditingkatkan seiring dengan tingginya standar kepuasan konsumen dan semakin tingginya kompetisi antara organisasi sejenis. Berdasarkan uraian diatas, produktivitas dirumuskan sebagai berikut:

$$
\text { Produktivitas }=\frac{\text { Efektivitasmenghasikanoutput }}{\text { Efisiensimenggunakaimput }}
$$

Kaitan antara efektivitas, efisiensi, produktivitas, dan kualitas dapat terangkai dalam skema berikut ini: 


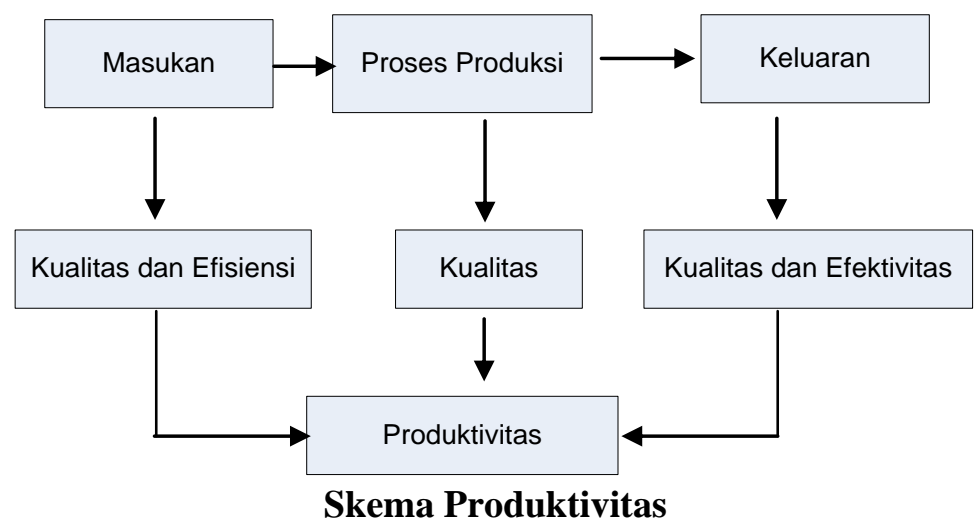

\section{METODOLOGI PENELITIAN}

Jenis, Pengumpulan, dan Pengolahan Data

Data yang dipakai dalam penelitian ini adalah data primer dan data sekunder. Sugiyono (2014). Data primer diperoleh dari pengamatan serta wawancara langsung dengan sumber yang berhubungan dengan objek yang diteliti, yaitu mengenai data aderet, defekta, resep, dan waktu pelayanan yang dicatat berdasarkan proses pelayanan saat pasien/pembawa resep memberikan resep ke apotek. Wawancara dilakukan dengan pihak apoteker, asisten apoteker, dan reseptur pada depo pelayanan yang bersangkutan. Sedangkan data sekunder diperoleh dari dokumentasi/arsip perusahaan, dan studi pustaka mengenai segala sesuatu yang relevan dengan penelitian ini, baik dari buku-buku, jurnal, maupun situs internet.

\section{Teknik Analisis Data}

Penelitian ini dimulai dengan pengamatan dan pengumpulan data di Apotek dibawah pengawasan Kepala Unit SDM dan Pelayanan. Dari hasil pengamatan dibuat perhitungan tentang beban kerja (Work Load) dengan metoda direct sampling, dimana merupakan sampling pekerjaan berdasarkan aktivitas yang dilakukan pada titik waktu tertentu dan dianggap mewakili suatu aktivitas pada titik waktu tersebut. Kemudian dibuat perhitungan produktivitas berdasarkan data trend jumlah resep dan data trend jumlah karyawan.

Didapat hasil dari kedua perhitungan tersebut diatas yang kemudian dianalisis dan menghasilkan adanya indikasi dan hipotesa terhadap faktor-faktor yang mempengaruhi produktivitas. Kemudian dianalisa lebih lanjut hal-hal yang mempengaruhi produktivitas tersebut yaitu dari sisi time management.

\section{HASIL PENELITIAN DAN PEMBAHASAN \\ Pengukuran Beban Kerja}

Untuk mengukur beban kerja karyawan Apotek digunakan pengukuran terhadap dampak, yaitu beban yang terukur dalam parameter pemakaian waktu kerja yang digunakan oleh pemegang jabatan. Asumsi-asumsi dan batasan yang digunakan adalah :

- Beban kerja karyawan yang dianalisis sebagai sample adalah karyawan depo IPD dan OPD 2 yang bekerja pada shift 1 (07.00-14.30 WIB).

- Pemegang jabatannya terdiri dari Apoteker, Asisten Apoteker, dan Reseptur.

- Hasil perhitungan beban kerja dianggap cukup mewakili dari keseluruhan beban kerja karyawan (berdasarkan profesi masing-masing) yang ada di depo-depo pelayanan selama 1 tahun.

- Beban kerja dihitung berdasarkan job description dari masing-masing profesi. 
- Persentase beban kerja dikatakan tinggi: $80 \%-100 \%$

Berdasarkan hasil perhitungan, maka dapat dilihat bahwa beban kerja dari masingmasing profesi di Apotek sudah sangat tinggi. Berikut hasil perhitungan beban kerja ratarata dari masing-masing profesi.

Tabel 1. Hasil Pengukuran Beban Kerja Karyawan Apotek

\begin{tabular}{|l|c|c|c|}
\hline Unit & $\begin{array}{c}\text { Beban Kerja } \\
\text { Apoteker (\%) }\end{array}$ & $\begin{array}{c}\text { Beban Kerja } \\
\text { Asisten Apoteker (\%) }\end{array}$ & $\begin{array}{c}\text { BebanKerja } \\
\text { Reseptur (\%) }\end{array}$ \\
\hline IPD & 109.3 & 95.7 & 91.9 \\
\hline OPD2 & 105.7 & 99.1 & 96.1 \\
\hline
\end{tabular}

\section{Analisis Beban Kerja}

Berdasarkan pengukuran diatas dapat dilihat bahwa beban kerja karyawan Apotek sangat tinggi yaitu mulai dari 91,9\% hingga 109,35\%. Apoteker memiliki beban kerja tertinggi, hingga melebihi $100 \%$, hal ini dikarenakan Apoteker berperan sebagai penanggung-jawab dari depo pelayanan, mulai dari memberikan penjelasan terhadap pasien/pembawa resep hingga monitoring terhadap keadaan depo pelayanannya baik dari segi kinerja karyawan maupun perencanaan untuk persediaan obat-obatan, sehingga untuk dapat memenuhi beban kerjanya dibutuhkan suatu usaha yang lebih dibandingkan Asisten Apoteker dan Reseptur yang walaupun beban kerjanya juga sangat tinggi, tetapi masih berada dibawah $100 \%$.

Perbedaan beban kerja Apoteker di depo IPD dan OPD2 antara lain disebabkan oleh waktu pelayanan dan jumlah karyawan per-profesi dari depo-depo tersebut. Pada depo IPD memiliki waktu pelayanan 24 jam (terdiri dari 3 Shift kerja) sedangkan waktu pelayanan dari depo OPD2 waktu pelayanannya hanya 7,5 jam (terdiri dari 1 shift kerja). Walaupun Apoteker di depo IPD tidak selalu ikut bertugas selama 24 jam, tetapi kinerja karyawan di depo IPD (shift 1,2 dan 3) tetap menjadi tanggung jawab dari Apoteker IPD. Hal inilah yang membuat pengukuran beban kerja terhadap Apoteker di depo IPD lebih tinggi dibandingkan dengan Apoteker di depo OPD2. Namun Apoteker di depo OPD 2 memiliki tugas lain yaitu bertanggungjawab terhadap Pusat Informasi Obat (PIO).

Untuk Asisten Apoteker dan Reseptur di depo OPD2 beban kerjanya lebih tinggi dibandingkan dengan di depo IPD. Hal ini disebabkan oleh jumlah Asisten Apoteker dan Reseptur di depo IPD lebih banyak jika dibandingkan dengan di depo OPD2. Karena beban kerja sangat tergantung dari jumlah resep dan jumlah pasien, maka jumlah karyawan yang lebih banyak pada depo dapat meringankan beban kerja karyawan yang bersangkutan.

\section{Pengukuran Produktivitas}

Pengukuran produktivitas Apotek diperoleh dengan membagi antara jumlah resep dengan jumlah karyawan.

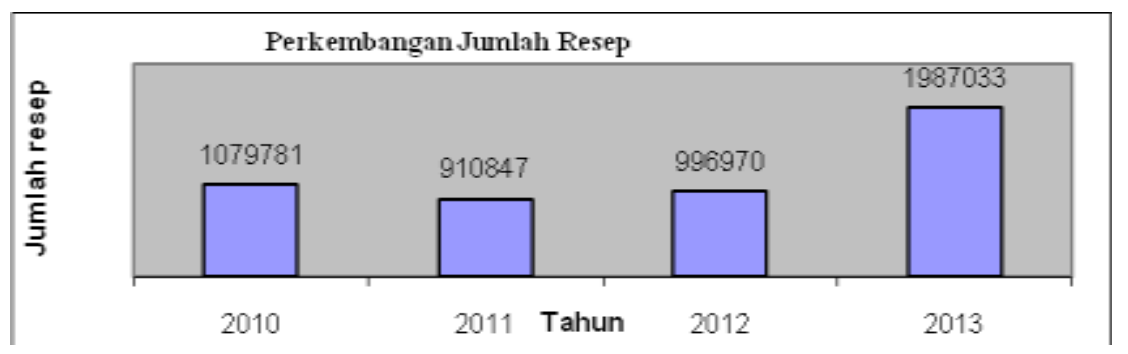




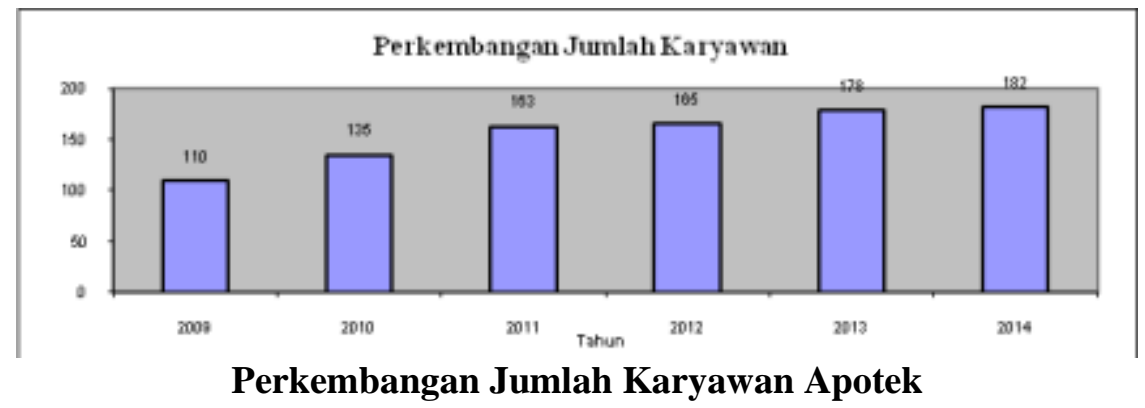

Tabel. 2 Produktivitas Kerja Apotek

\begin{tabular}{|c|c|c|c|c|}
\hline Tahun & $\mathbf{2 0 1 0}$ & $\mathbf{2 0 1 1}$ & $\mathbf{2 0 1 2}$ & $\mathbf{2 0 1 3}$ \\
\hline Produktivitas & 7998.3 & 5588 & 6042.2 & 11163.1 \\
\hline
\end{tabular}

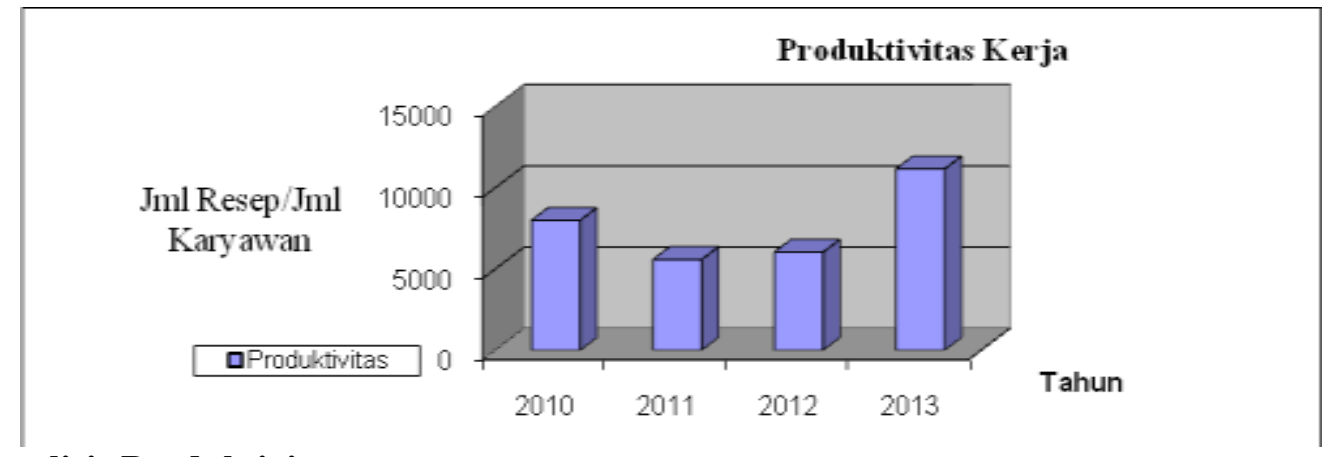

Analisis Produktivitas

- Secara keseluruhan produktivitas kerja karyawan Apotek mengalami peningkatan, terutama dari tahun 2012 ke tahun 2013. Namun perlu dicermati juga bahwa pada tahun 2011 terjadi penurunan tingkat produktivitas meskipun ada peningkatan jumlah karyawan.

- Peningkatan atau penurunan produktivitas kerja karyawan pada depo-depo pelayanan ini sangat tergantung pada jumlah resep yang dilayani.

\section{Analisis Beban Kerja vs Produktivitas Kerja Karyawan Apotek}

Dengan membandingkan antara analisis beban kerja dan analisis produktivitas kerja karyawan Apotek diatas, dapat dilihat bahwa beban kerja untuk masing-masing profesi dalam Apotek sudah sangat tinggi, sehingga dapat mengakibatkan karyawan bekerja menjadi kurang fokus dan efektif bahkan pelayanan terhadap pasien pun berkurang. Pada tahun 2011 terdapat penambahan jumlah karyawan sedangkan jumlah resep mengalami penurunan, sehingga dapat dikatakan bahwa tingkat produktivitas kerja karyawan Apotek juga mengalami penurunan karena tinggi rendahnya tingkat produktivitas kerja karyawan sangat tergantung dari jumlah resep yang dilayani. Penambahan jumlah karyawan yang terjadi setiap tahun dialokasikan pada bagian pelayanan maupun non pelayanan.

Analisis Produktivitas Kerja Berdasarkan Proses Pemesanan dan Pengiriman Obat

Analisis ini untuk mengetahui sejauh mana peran SDM sebagai penyebab dari: ketidaksesuaian antara pemesanan dan penerimaan obat apabila dilihat dari aderet dan defekta, permintaan obat yang double yaitu dipesan di aderet dan di defekta, dan pemesanan obat yang double pada aderet di hari yang sama. 
Defekta adalah form pemesanan obat yang jadwalnya rutin 3 kali dalam satu minggu yaitu terjadi pada hari Selasa, Kamis dan Sabtu. Sementara aderet adalah form permintaan obat yang jadwalnya tidak rutin, diluar defekta. Berikut gambaran dari hasil proses pengiriman obat yang terjadi di depo pelayanan, sample diambil selama 1 minggu di depo pelayanan IPD.

Tabel.3 Hasil Proses Pemesanan dan Pengiriman Obat

\begin{tabular}{|l|r|}
\hline Jumlah obat yang dikirim sesuai permintaan & $\mathbf{1 2 . 2 7 3}$ \\
\hline Jumlah obat yang dikirim tidak sesuai dengan permintaan & $\mathbf{3 . 1 3 6}$ \\
\hline Jumlah obat yang tidak dikirim & $\mathbf{7 . 8 3 0}$ \\
\hline Total jumlah permintaan obat di defekta & $\mathbf{2 3 . 2 3 9}$ \\
\hline
\end{tabular}

Dari tabel diatas terlihat bahwa perencanaan persediaan obat di depo pelayanan adalah kurang baik, sehingga dapat dikatakan bahwa kinerja karyawan pada depo pelayanan tersebut adalah kurang baik. Perencanaan persediaan obat yang kurang baik dapat diakibatkan karena tingginya beban kerja dari para karyawan sehingga tidak fokus untuk membuat dan memperkirakan jenis dan jumlah obat yang harus dipesan. Ketidaksesuaian ini juga dapat disebabkan oleh sistem control dan administrasi yang kurang baik dari pihak manajemen.

\section{Waktu Pelayanan}

Waktu pelayanan pada kondisi existing dari proses pembelian dan permintaan obat hingga sampai ke proses pelayanan pasien ruang rawat jalan (OPD2) dan ruang rawat inap (IPD) terdiri 35 proses operasi, 9 proses pemeriksaan, 12 proses transportasi dan 7 proses penyimpanan yang dilalui dalam proses bisnis sehingga menghabiskan banyak waktu dalam pelaksanaannya. Para karyawan bekerja dengan sistem shift. Pembagian waktunya adalah shift 1: 07.00 - 14.30 WI (dengan jadwal istirahat makan siang yang tidak menentu), shift 2: $14.30-20.30 \mathrm{WIB}$, dan shift 3: $20.30-07.00$ WIB.

Sample waktu pelayanan menunjukkan waktu pelayanan yang diberikan oleh para petugas di apotek sejak pasien/pembawa resep datang untuk menyerahkan resepnya sampai obat diterima oleh pasien/pembawa resep, dimana saat pasien/pembawa resep menerima obat tersebut juga mendapatkan penjelasan tentang penggunaan obat dari apoteker di depo yang bersangkutan.

Lamanya waktu pelayanan berdasarkan jumlah resep yang diminta dan sesuai dengan resep yang dibawa oleh pasien/pembawa resep dan berdasarkan jenis obat yang diminta. Apabila obat yang diminta merupakan jenis obat umum, maka dibutuhkan waktu tunggu yang relatif lebih singkat (antara 3-30 menit) apabila dibandingkan dengan resep yang didalamnya terdapat jenis obat yang harus diracik terlebih dahulu (rata-rata $>30$ menit). 
Tabel. 4

Sample waktu pelayanan untuk pasien rawat inap (IPD) dan rawat jalan (OPD2)

(dalam menit)

\begin{tabular}{|r|c|c|c|c|c|c|}
\hline \multirow{2}{*}{ No } & \multicolumn{6}{|c|}{ Waktu Pelayanan di Depo } \\
\cline { 2 - 7 } & \multicolumn{3}{|c|}{ IPD } & \multicolumn{3}{c|}{ OPD2 } \\
\hline 1 & $11^{\prime}$ & $76^{\prime}$ & $19^{\prime}$ & $8^{\prime}$ & $5^{\prime}$ & $3^{\prime}$ \\
\hline 2 & $3^{\prime}$ & $6^{\prime}$ & $5^{\prime}$ & $20^{\prime}$ & $3^{\prime}$ & $4^{\prime}$ \\
\hline 3 & $3^{\prime}$ & $42^{\prime}$ & $19^{\prime}$ & $5^{\prime}$ & $7^{\prime}$ & $7^{\prime}$ \\
\hline 4 & $26^{\prime}$ & $86^{\prime}$ & $2^{\prime}$ & $8^{\prime}$ & $6^{\prime}$ & $9^{\prime}$ \\
\hline 5 & $46^{\prime}$ & $100^{\prime}$ & $38^{\prime}$ & $8^{\prime}$ & $12^{\prime}$ & $3^{\prime}$ \\
\hline 6 & $6^{\prime}$ & $52^{\prime}$ & $29^{\prime}$ & $55^{\prime}$ & $4^{\prime}$ & $25^{\prime}$ \\
\hline 7 & $33^{\prime}$ & $24^{\prime}$ & $28^{\prime}$ & $24^{\prime}$ & $3^{\prime}$ & $32^{\prime}$ \\
\hline 8 & $48^{\prime}$ & $72^{\prime}$ & $12^{\prime}$ & $3^{\prime}$ & $18^{\prime}$ & $3^{\prime}$ \\
\hline 9 & $46^{\prime}$ & $34^{\prime}$ & $19^{\prime}$ & $3^{\prime}$ & $6^{\prime}$ & $45^{\prime}$ \\
\hline 10 & $50^{\prime}$ & $43^{\prime}$ & $17^{\prime}$ & $4^{\prime}$ & $3^{\prime}$ & $27^{\prime}$ \\
\hline
\end{tabular}

\section{Hasil Perhitungan Sample :}

- Rata-rata waktu pelayanan di IPD $=33,17$ menit

- Rata-rata waktu pelayanan di OPD2 = 12,1 menit

\section{Beban Kerja dikaitkan dengan Time Management Pelayanan}

Dalam melaksanakan aktivitas kerjanya, karyawan dibatasi oleh waktu kerja (jam kerja), dimana waktu kerja tersebut harus dapat dijalani secara efektif dan efisien, karena mencerminkan tingkat produktivitas yang dihasilkan. Keefektifan dan keefisienan waktu kerja tersebut dapat dilihat dari salah satu faktor penunjang, yaitu manajemen waktu yang baik. Apabila masing-masing profesi yang ada di depo Apotek (Apoteker, Asisten Apoteker, dan Reseptur) dapat bekerja sama dan memberikan kontribusi dengan baik, maka efektivitas di Apotek akan meningkat.

Efektivitas mengarah pada pencapaian tujuan unjuk kerja yang maksimal yang berkaitan dengan kualitas, kuantitas, dan waktu, maka manajemen waktu yang baik sangat diperlukan untuk mengarahkan alokasi waktu kerja terhadap butir-butir aktivitas (job description) yang harus dilakukan sehingga dapat tercapai efektivitas dan efisiensi waktu.

Untuk dapat mengukur waktu secara efektif, masing-masing profesi terlebih dahulu harus mengerti dengan jelas dan pasti apa yang harus dikerjakannya, bagaimana ia akan menggunakan waktu kerjanya tersebut, dan menetukan skala prioritas dari variasi tugas dan kesibukan dalam pekerjaannya, bekerja semaksimal mungkin untuk meningkatkan performansinya dan mengurangi atau bahkan menghilangkan aktivitas yang tidak perlu yang dapat menghambat pekerjaannya.

\section{SIMPULAN DAN SARAN}

Berdasarkan hasil analisis dan penelitian, dapat dikatakan bahwa beban kerja dan produktivitas para karyawan yang ada di Apotek ini sudah sangat tinggi, hal ini disebabkan karena jumlah pelayanan resep yang banyak dan proses aliran obat yang terlalu panjang. Beban kerja dan produktivitas sangat tinggi menyebabkan karyawan apotek bekerja kurang fokus sehingga tingkat kesalahan yang dilakukan pun dapat meningkat. 
Dengan melihat aliran obat dari proses pemesanan dan pembelian hingga proses obat tersebut sampai ke depo pelayanan OPD2 dan IPD melalui proses yang cukup lama dan panjang, maka penulis memberikan usulan perbaikan dalam hal time management dan peningkatan waktu pelayanan terhadap pasien/pembawa resep. Contohnya adalah pada saat jam-jam diluar peak hour disarankan agar para karyawan dapat mengerjakan sesuatu yang lebih produktif, seperti memperbaiki tata letak obat agar dapat mempermudah dan mempersingkat waktu pelayanan karena obat yang diminta telah tertata dengan baik dan dapat dengan mudah diambil serta elakukan pencatatan untuk stok obat yang kosong agar tidak terjadi double order. Sebagai sistem controlling untuk menghindari terjadinya double entry dan meminimalisir human error, maka disarankan agar apotek menerapkan teknologi informasi yang terintegrasi (integrated computerized) untuk seluruh depo pelayanan. Selain itu agar para karyawan dapat meningkatkan performa-nya dan termotivasi untuk meningkatkan produktivitasnya, maka harus diberikan reward dan punishment.

\section{DAFTAR PUSTAKA}

Adebisi, J. F. 2013. Time management practices and its effect on business performance. Canadian Social Science, 9(1). Canadian Research \& Development Center of Sciences and Cultures, Montreal, Canada

Dhania, Dhini Rama . 2010. Pengaruh Stres Kerja dan Beban Kerja Terhadap Kepuasan Kerja pada Medical Representatif di Kota Kudus Jurnal Ilmiah Volume 1, Nomor 1, Universitas Muria Kudus

Herjanto, E. 2007. Manajemen Operasi. Grasindo. Jakarta.

International Labour Office. 1974. Introduction to Work Study, Revised Edition, Geneva: ILO Publication.

Jones J.R. 2012. Time is on your side. Nursing Standard, 26 (38) Hal 70-71

Munandar, A.S. 2012. Psikologi Industri dan Organisasi. Penerbit Universitas Indonesia. Jakarta.

Peraturan Menteri Dalam Negeri No. 12 tentang Pedoman Analisis Beban Kerja Di Lingkungan Departemen Dalam Negeri dan Pemerintah Daerah. 2008

Peraturan Menteri Kesehatan Republik Indonesia No.58 tentang Standar Pelayanan Kefarmasian di Rumah Sakit. 2014. Jakarta: Depkes

Peraturan Menteri Kesehatan Republik Indonesia No.35 Tahun 2014 Tentang Standar Pelayanan Kefarmasian di Apotek. 2014. Jakarta: Depkes

Undang-Undang Republik Indonesia No.36 tentang Kesehatan. 2009. Jakarta.

Singh, D. \& Jain, S.C. 2013. Working process of time management in SAP HR module. International Journal of Management Research and Reviews, 3. Society of Scientific Research and Education (SSRE), Meerut, India.

Sinungan, Muchdarsyah. 2008. Produktivitas Apa dan Bagaimana. Bumi Aksara: Jakarta. Sugiyono. 2014. Metode Penelitian Manajemen. Alfabeta: Bandung 